\title{
Identification of a Hidden Resistance Gene in Tetraploid Wheat Using Laboratory Strains of Pyricularia oryzae Produced by Backcrossing
}

\author{
Christian Joseph R. Cumagun, Vu Lan Anh, Trinh Thi Phuong Vy, Yoshihiro Inoue, \\ Hokuto Asano, Gang-Su Hyon, Izumi Chuma, and Yukio Tosa
} All authors: Graduate School of Agricultural Sciences, Kobe University, Kobe 657-8501, Japan; first author: Crop Protection Cluster,
University of the Philippines Los Baños, College, Laguna, 4031, Philippines; and sixth author: RIKEN Yokohama Institute, Tsurumi-ku,
Yokohama, 230-0045 Japan.

Accepted for publication 26 November 2013.

\begin{abstract}
Cumagun, C. J. R., Anh, V. L., Vy, T. T. P., Inoue, Y., Asano, H., Hyon, G.-S., Chuma, I., and Tosa, Y. 2014. Identification of a hidden resistance gene in tetraploid wheat using laboratory strains of Pyricularia oryzae produced by backcrossing. Phytopathology 104:634-640.

In the process $\left(\mathrm{BC}_{3} \mathrm{~F}_{1}\right.$ generation) of backcrossing an Avena isolate of Pyricularia oryzae with a Triticum isolate, color mutants with white mycelia were obtained. These white mutants lacked virulence on all (31/31) hexaploid and most (28/32) tetraploid wheat lines tested. In a $\mathrm{BC}_{4} \mathrm{~F}_{1}$ population, white and black cultures segregated in a 1:1 ratio, suggesting that the mutant phenotype is controlled by a single gene. Furthermore, the mycelial color was perfectly linked with avirulence in the $\mathrm{BC}_{4} \mathrm{~F}_{1}$ population; white cultures were all avirulent on common wheat (Triticum aestivum) 'Norin 4' (N4) whereas black cultures were all viru-

lent. White cultures in the $\mathrm{BC}_{3} \mathrm{~F}_{1}$ and $\mathrm{BC}_{4} \mathrm{~F}_{1}$ generations were also avirulent on tetraploid wheat (T. dicoccoides) accession 'KU109' (Tat4), which was susceptible to all cultures derived from the parental wild isolates through the $\mathrm{BC}_{2} \mathrm{~F}_{1}$ generation. A cross between Tat 4 and a susceptible tetraploid (T. paleocolchicum) accession 'KU196' (Tat14) produced resistant and susceptible $F_{2}$ seedlings in a 3:1 ratio against the white cultures. In the $\mathrm{F}_{3}$ generation homozygous resistant/segregating/homozygous susceptible lines segregated in a 1:2:1 ratio. These results suggest that the resistance of Tat 4 to the white cultures is controlled by a single major gene. This gene, tentatively designated as $\operatorname{Rmg} T d(t)$, is considered to be a hidden resistance gene because it was not detected with the $\mathrm{Br} 58, \mathrm{~F}_{1}$, $\mathrm{BC}_{1} \mathrm{~F}_{1}$, or $\mathrm{BC}_{2} \mathrm{~F}_{1}$ cultures. Cytological analysis revealed that the moderate resistance controlled by $\operatorname{RmgTd}(t)$ was associated with a hypersensitive reaction of mesophyll cells.
\end{abstract}

Blast disease is caused by the filamentous fungus Pyricularia oryzae Cavara (Magnaporthe oryzae B. C. Couch) (3) and occurs on rice, wheat, and several genera of grasses $(14,20)$. Blast is a new field disease of wheat first reported in Parana, Brazil, in 1985, and later causing considerable yield losses (26). The use of resistant cultivars remains the most effective, economical, and environmentally sound management strategy, at least for rice blast; however, resistant cultivars are lacking for wheat blast, considering that the pathogen has become a major threat to stable wheat production $(10,26,27)$.

$P$. oryzae consists of several host-specific subgroups or pathotypes (14) such as Oryza isolates pathogenic on rice (Oryzae sativa), Setaria isolates pathogenic on foxtail millet (Setaria italica), Triticum isolates pathogenic on common wheat (Triticum aestivum), Avena isolates pathogenic on oat (Avena sativa) (19), and Lolium isolates pathogenic on perennial ryegrass (Lolium perenne) (25). This specificity, which determines host species range, has been categorized into plant species specificity, whereas the specificity that determines cultivar range within a given host range has been termed cultivar specificity (7). P. oryzae is known to adapt easily to cultivar resistance. During the past 50 years, resistance genes introduced into rice cultivars were quickly overcome by new races of $P$. oryzae (15). On the other hand, plant

Corresponding author: Y. Tosa; E-mail address: tosayuki@kobe-u.ac.jp

* The $\boldsymbol{e}$-Xtra logo stands for "electronic extra" and indicates that the online version contains two supplemental tables and two supplemental figures.

http://dx.doi.org/10.1094/PHYTO-04-13-0106-R

(C) 2014 The American Phytopathological Society species specificity appears to be stable. In the mechanism of plant species specificity, we may find a clue to the establishment of a breeding system for durable resistance.

Silue et al. (21) demonstrated that race-cultivar specificity follows the gene-for-gene relationship (5). The genetic mechanism of host species specificity, however, remains to be elucidated. Crossing of fungal strains belonging to different hostspecific subgroups allows identification of avirulence genes involved in host species specificity. Takabayashi et al. (23) crossed a Triticum isolate (Br48) with an Avena isolate (Br58) and demonstrated that the specificity on wheat was conditioned by two loci, Pwt3 and Pwt4. They designated the avirulence/virulence alleles at these loci as PWT3/pwt3 and PWT4/pwt4, respectively, suggesting that these genes are under the control of gene-for-gene interactions. A corresponding resistance gene to PWT4 designated as Rwt4 (Rmgl) was also identified. Rwt4 is the first known wheat gene for resistance to $P$. oryzae. This gene confers the resistance of wheat to inappropriate isolates from Avena (23) but is ineffective against Triticum isolates. Their interaction was found to be insensitive to high temperature whereas the interaction of $P W T 3$ with its corresponding putative resistance gene (Rwt3) was temperature sensitive and ineffective at high temperatures (23). These conditions provide a good model system to study the genetic mechanism of host species specificity of $P$. oryzae.

$P W T 3$ is assumed to be a fundamental gene that ubiquitously controls avirulence of Avena isolates on wheat. To establish the functionality of $P W T 3$, attempts were made to produce a nearisogenic strain of Triticum isolate Br48 that carries PWT3 by continuous backcrosses. In the process of backcrossing, a new 
type of fungal gene associated with mycelial color and avirulence was found. This gene was obviously different from PWT3 but had a characteristic that simulated an avirulence gene because it corresponded to a "hidden" resistance gene, designated here as $\operatorname{RmgTd}(t)$. Genetic behavior of these unique "complementary" genes are reported here.

\section{MATERIALS AND METHODS}

Plant and fungal materials. Plant materials used for the preliminary screening were 31 hexaploid and 32 tetraploid wheat lines (Supplemental Table 1). Of these 63 lines, T. aestivum 'Norin 4' (N4), T. dicoccoides accession 'KU109' (laboratory code Tat4), and T. paleocolchicum accession 'KU156' (laboratory code Tat14) were chosen as representatives for segregation analyses. Tat14 was used as a susceptible control. P. oryzae strains used in the present study were Avena isolate Br58, Triticum isolate $\mathrm{Br} 48$, and progenies derived from their crosses. $\mathrm{Br} 58$ and Br48 were collected in Brazil in 1990. These cultures have been maintained on barley seed media (6) at $4^{\circ} \mathrm{C}$ in the Laboratory of Plant Pathology, Kobe University. They were transferred to a potato dextrose agar slant just before use and grown at room temperature. Slant cultures, 1 week to 3 months old, were used for experiments.

Genetic crosses of fungal strains. A cross between $\mathrm{Br} 48$ (pathogenic on wheat) and Br58 (pathogenic on oat) was performed previously (23). To remove effects of genes other than $P W T 3$, an $\mathrm{F}_{1}$ culture (73Q2) with genotype PWT3;pwt4 was chosen, and backcrossed with Br48 four times (Fig. 1). Progenies produced by backcrosses were checked by DNA fingerprinting. Genomic DNA extracted as described previously (17). were digested with EcoRI (Takara Bio, Shiga, Japan), electrophoresed on $0.7 \%$ agarose gel in $0.5 \times$ Tris-acetate-EDTA buffer, and transferred onto a nylon membrane Hybond N+filter (GE Healthcare, Buckinghamshire, UK). The membrane was hybridized with pPO-H (4) containing a fragment of Pot2 (13). Labeling and detection were performed using the AlkPhos Direct Labeling and Detection System (GE healthcare).

Infection assay. Wheat seed were pregerminated on moistened filter papers for 2 days, sown in vermiculite (Asahi-Kogyo, Okayama, Japan), supplied with liquid fertilizer in a seedling case ( 5.5 by 15 by $10 \mathrm{~cm}$ ), and grown at $22^{\circ} \mathrm{C}$ in a controlled environment room with a 12-h photoperiod of fluorescent lighting for 7 days. Mycelial plugs of fresh slant cultures (3 weeks to 3 months old) were transferred to oatmeal agar plates (oatmeal, $20 \mathrm{~g}$; sucrose, $10 \mathrm{~g}$; and agar, 10 to $15 \mathrm{~g}$ in $500 \mathrm{ml}$ of distilled water) and incubated at $22^{\circ} \mathrm{C}$ for 10 days. Conidia produced as described previously (16) were suspended in distilled water with $0.01 \%$ Tween 20 and adjusted to 1 to $2 \times 10^{5}$ spores $/ \mathrm{ml}$. The conidial suspension was sprayed on the adaxial surface of 7-day-old primary leaves. The inoculated plants were incubated in a dark, humid box at $22^{\circ} \mathrm{C}$ for $24 \mathrm{~h}$. Then, they were transferred to a growth chamber controlled at $22^{\circ} \mathrm{C}$ with a 12 -h photoperiod. Disease intensity was evaluated 4 to 5 days after inoculation. Disease ratings consisted of six progressive levels from 0 to 5: $0=$ no visible evidence of infection; $1=$ pinpoint spots; $2=$ small lesions $(<1.5 \mathrm{~mm}) ; 3=$ lesions of intermediate size $(<3 \mathrm{~mm}) ; 4=$ large, typical lesions; and $5=$ complete blighting of leaf blades. These lesions were classified into two categories on the basis of their color; that is, brown (B) and green (G). Infection types were represented by the combination of the size (intensity) score and the color code. Infection types $0,1 \mathrm{~B}, 2 \mathrm{~B}$, and $3 \mathrm{~B}$ were considered to be resistant and infection types $3 \mathrm{G}, 4 \mathrm{G}$, and $5 \mathrm{G}$ to be susceptible. Sometimes lesions of size 2 and 3 were accompanied by both brown and green tissues. These types of lesions, designated as $2 \mathrm{BG}$ and $3 \mathrm{BG}$, respectively, were considered resistant according to Hyon et al. (9). Each infection assay was repeated at least three times.
Molecular mapping. Simple-sequence repeat (SSR) markers for the P. oryzae genome (29) were screened to find PWT3flanking markers. Polymerase chain reaction (PCR) for the SSR markers was performed in a $15-\mu \mathrm{l}$ reaction mixture containing 20 to $50 \mathrm{ng}$ of genomic DNA, $1 \times$ PCR buffer $(10 \mathrm{mM}$ Tris- $\mathrm{HCl}[\mathrm{pH}$ 8.4], $50 \mathrm{mM} \mathrm{KCl}$, and $1.5 \mathrm{mM} \mathrm{MgCl}_{2}$ ), $200 \mu \mathrm{M}$ each dNTP, $0.5 \mu \mathrm{M}$ each of the forward and reverse primers, and $1 \mathrm{U}$ of Taq polymerase. All SSR fragments were amplified with a routine PCR program: $5 \mathrm{~min}$ at $94^{\circ} \mathrm{C} ; 30$ cycles of $30 \mathrm{~s}$ at $94^{\circ} \mathrm{C}, 30 \mathrm{~s}$ at $55^{\circ} \mathrm{C}$, and $1 \mathrm{~min}$ at $72^{\circ} \mathrm{C}$; and $5 \mathrm{~min}$ at $72^{\circ} \mathrm{C}$ for final extension. Amplified products were electrophoresed in $4.0 \%$ polyacrylamide gels (Nacalai Tesque, Kyoto, Japan) and the banding patterns were visualized using SILVER SEQUENCE DNA Staining Reagents (DNA Silver Staining System; Promega Corp., Madison, WI). Molecular weight size markers V and VIII (Boehringer, Mannheim, Germany) were used as standard size markers.

SSR markers for the wheat genome $(22,24)$ were screened to identify the chromosome carrying $\operatorname{RmgTd}(t)$. Linkage analysis was performed using $86 \mathrm{~F}_{3}$ lines derived from the cross between Tat4 (resistant) and Tat14 (susceptible), as described by Inoue et al. (11).

Cytological analysis. Inoculated primary leaves were harvested $60 \mathrm{~h}$ after inoculation and boiled in alcoholic lactophenol (lactic acid/phenol/glycerol/distilled water/ethanol $=1: 1: 1: 1: 8$, $\mathrm{vol} / \mathrm{vol} / \mathrm{vol} / \mathrm{vol} / \mathrm{vol}$ ) for $2 \mathrm{~min}$ for fixation. The specimens were mounted on a slide glass in $50 \%$ glycerol and observed under bright and dark fields of an Olympus BX51 microscope (Olympus, Tokyo) fitted with an exciter filter B. Sites with more than one appressoria on one epidermal cell were excluded from counting. This experiment was repeated twice. In total, 300 appressoria on three leaves were counted for each isolate or progeny in each replication. Cell death was visualized with trypan blue staining, as described previously (9).

\section{RESULTS}

Appearance and inheritance of a color mutation. 73Q2 (PWT3;pwt4), an $\mathrm{F}_{1}$ culture derived from Br58 (PWT3;PWT4) $\times$ Br48 (pwt3;pwt4), was backcrossed with Br48 (Fig. 1). Geno-

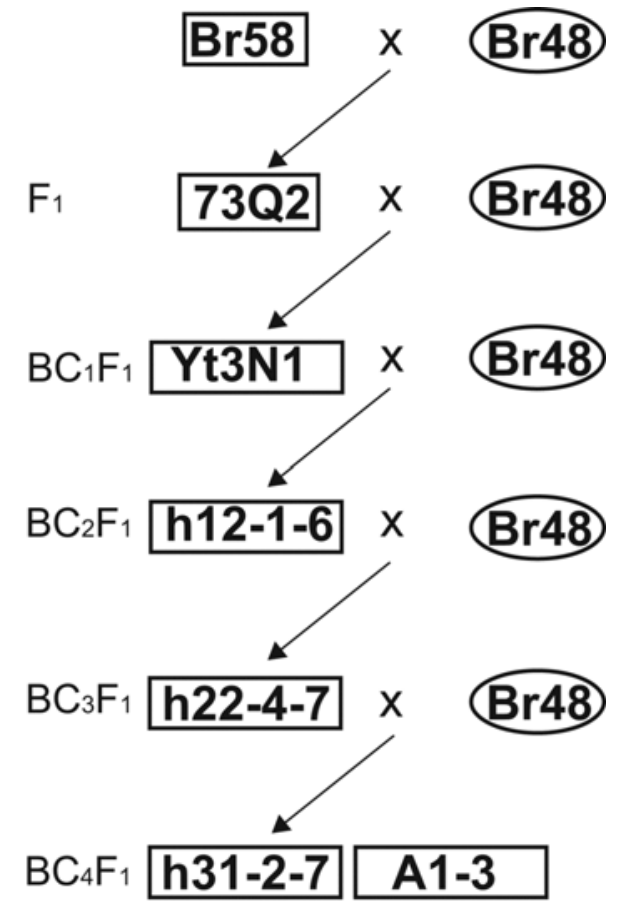

Fig. 1. Pedigree of representative cultures derived from backcrosses of Avena isolate Br58 with Triticum isolate Br48. 
types of the $\mathrm{BC}_{1} \mathrm{~F}_{1}$ cultures at the Pwt 3 locus were determined by spraying them on N4, with which $P W T 3$ had been first identified (23). Yt3N1, a $\mathrm{BC}_{1} \mathrm{~F}_{1}$ culture avirulent on $\mathrm{N} 4$ ( $P W T 3$ carrier), was chosen, and again backcrossed with $\mathrm{Br} 48$ (Fig. 1). The resulting $\mathrm{BC}_{2} \mathrm{~F}_{1}$ cultures were sprayed on $\mathrm{N} 4$, and an avirulent culture (h12-1-6) was further backcrossed with $\mathrm{Br} 48$. In the resulting $\mathrm{BC}_{3} \mathrm{~F}_{1}$ generation, we found several white cultures. In some sets (tetrads), white and black (normal) cultures segregated in a 1:1 ratio. An example is shown in Figure 2. Of eight $\mathrm{BC}_{3} \mathrm{~F}_{1}$ cultures derived from a single ascus (h22-4), four were white and four were black. The white cultures were considered to be color mutants because both parental isolates (h12-1-6 and Br48) produced black colonies. To reveal the inheritance of this mutation, white $\mathrm{BC}_{3} \mathrm{~F}_{1}$ culture h22-4-7 was further backcrossed with $\mathrm{Br} 48$. In the resulting $\mathrm{BC}_{4} \mathrm{~F}_{1}$ population derived from 11 asci, white and black cultures segregated in a 1:1 ratio (41:40) (Supple- mental Table 2), suggesting that this mutation involved a single gene. Fingerprinting with Pot2 (13) showed that all the white $\mathrm{BC}_{3} \mathrm{~F}_{1}$ cultures shared an identical profile with the black $\mathrm{BC}_{3} \mathrm{~F}_{1}$ siblings and their parents (h12-1-6 and Br48) (Supplemental Figure 1).

Association of the color mutation with avirulence. To check the association of the color mutation with pathogenicity, the eight $\mathrm{BC}_{3} \mathrm{~F}_{1}$ cultures derived from ascus h22-4 were sprayed on $\mathrm{N} 4$. The four white cultures were avirulent on N4 whereas the four black cultures were virulent (Fig. 2). Furthermore, in the segregating $\mathrm{BC}_{4} \mathrm{~F}_{1}$ population derived from $\mathrm{h} 22-4-7 \times \mathrm{Br} 48$, black colony color was perfectly concordant with virulence on $\mathrm{N} 4$ (Table 1).

Tetraploid accession Tat4, which is susceptible to all cultures from the parental Avena isolate $(\mathrm{Br} 58)$ through the $\mathrm{BC}_{2} \mathrm{~F}_{1}$ generation, showed a moderately resistant reaction to the white
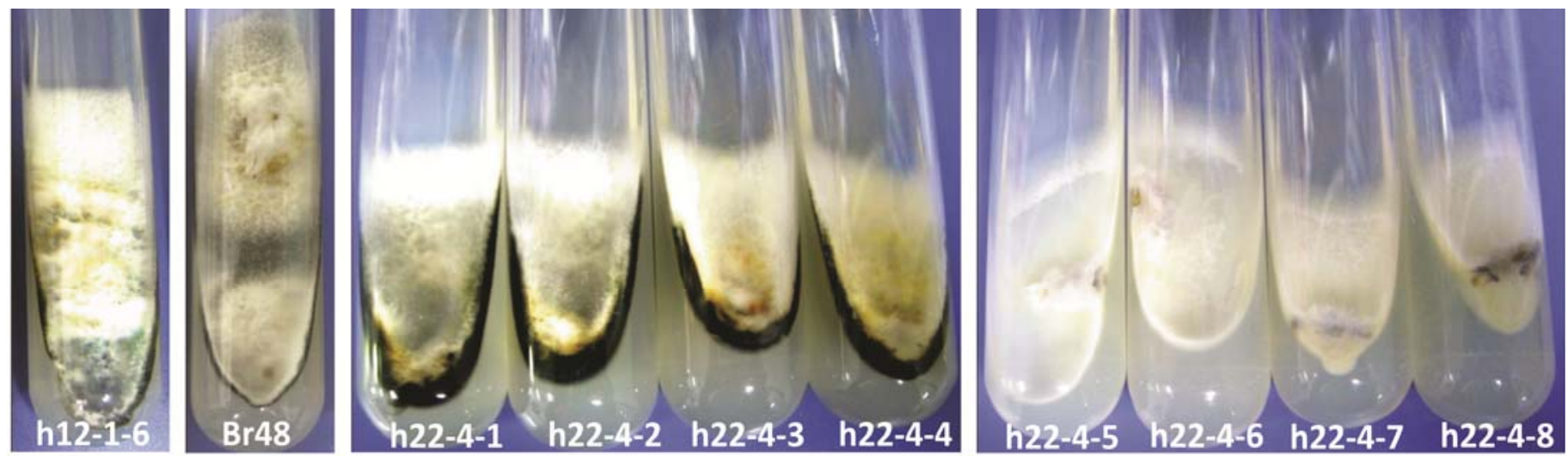

h12-1-6

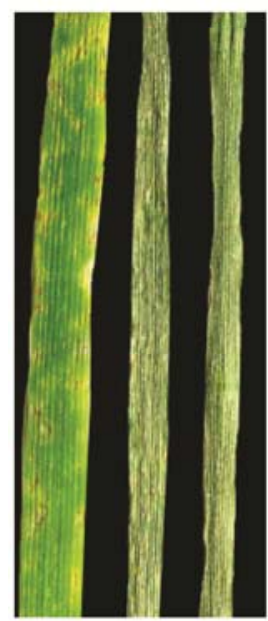

N4 Tat4 Tat14
Br48

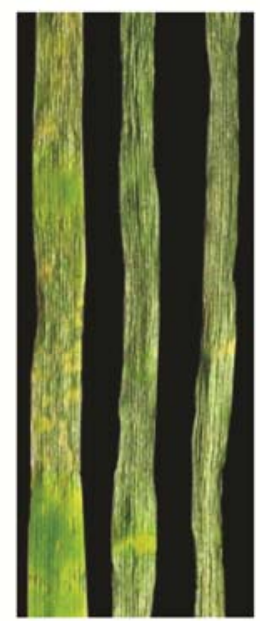

N4 Tat4 Tat14 h22-4-1

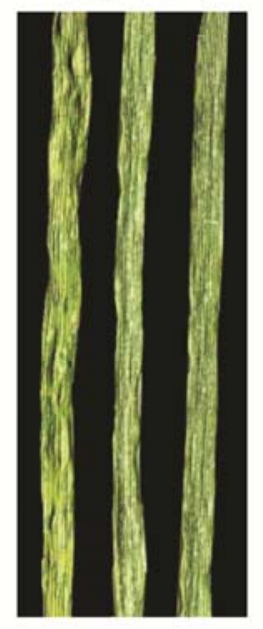

N4 Tat4 Tat14 h22-4-2

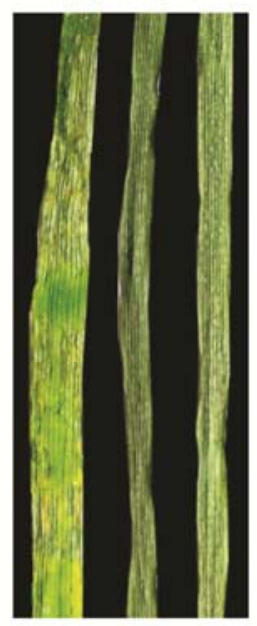

N4 Tat4 Tat14 h22-4-7

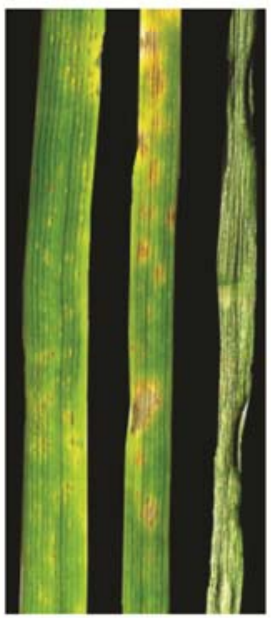

N4 Tat4 Tat14 h22-4-8

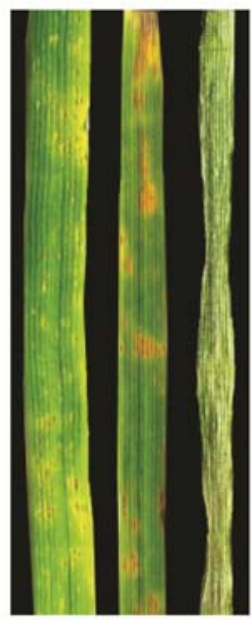

N4 Tat4 Tat14

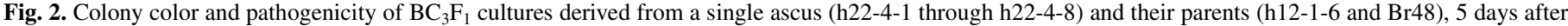
inoculation of N4, Tat4, and Tat14.

TABLE 1. Responses of wheat lines to Avena isolate Br58, Triticum isolate Br48, and progenies derived from backcrosses with Br48

\begin{tabular}{|c|c|c|c|c|c|c|c|c|c|c|c|}
\hline \multirow[b]{2}{*}{ Plant species } & \multirow[b]{2}{*}{ Line } & \multicolumn{6}{|c|}{ Infection type with } & \multicolumn{4}{|c|}{$\begin{array}{l}\text { Number of } \mathrm{BC}_{4} \mathrm{~F}_{1} \text { cultures } \\
\text { from h22-4-7 } \times \mathrm{Br}_{4} 8^{\mathrm{a}}\end{array}$} \\
\hline & & $\operatorname{Br} 58$ & $\begin{array}{c}73 \mathrm{Q}^{2} \\
\left(\mathrm{~F}_{1}\right)\end{array}$ & $\begin{array}{l}\mathrm{Yt} 3 \mathrm{~N} 1 \\
\left(\mathrm{BC}_{1} \mathrm{~F}_{1}\right)\end{array}$ & $\begin{array}{l}\mathrm{h} 12-1-6 \\
\left(\mathrm{BC}_{2} \mathrm{~F}_{1}\right)\end{array}$ & $\begin{array}{l}\mathrm{h} 22-4-7 \\
\left(\mathrm{BC}_{3} \mathrm{~F}_{1}\right)\end{array}$ & $\mathrm{Br} 48$ & $\begin{array}{l}\text { White } \\
\text { A }\end{array}$ & $\begin{array}{l}\text { White } \\
\text { V }\end{array}$ & $\begin{array}{c}\text { Black } \\
\text { A }\end{array}$ & $\begin{array}{c}\text { Black } \\
\text { V }\end{array}$ \\
\hline Triticum aestivum (6×) & N4 (Norin 4) & $0-1 \mathrm{~B}$ & $3 B G$ & $2 \mathrm{~B}$ & $2 \mathrm{~B}$ & $1 \mathrm{~B}$ & $4 \mathrm{G}$ & 41 & 0 & 0 & 40 \\
\hline T. dicoccoides $(4 \times)$ & Tat4 (KU109) & $5 \mathrm{G}$ & $5 \mathrm{G}$ & $5 \mathrm{G}$ & $5 \mathrm{G}$ & $3 \mathrm{~B}$ & $5 \mathrm{G}$ & 41 & 0 & 0 & 40 \\
\hline T. paleocolchicum $(4 \times)$ & Tat14 (KU156) & $5 \mathrm{G}$ & $5 \mathrm{G}$ & $5 G$ & $5 \mathrm{G}$ & $5 \mathrm{G}$ & $5 \mathrm{G}$ & 0 & 41 & 0 & 40 \\
\hline
\end{tabular}

a $\mathrm{A}=$ avirulent (infection type 0 to $3 \mathrm{BG}$ ) and $\mathrm{V}=$ virulent (infection type $3 \mathrm{G}$ to $5 \mathrm{G}$ ). 
$\mathrm{BC}_{3} \mathrm{~F}_{1}$ cultures (Fig. 2; Table 1). This moderately avirulent reaction of the $\mathrm{BC}_{3} \mathrm{~F}_{1}$ cultures on Tat 4 was inherited by the $\mathrm{BC}_{4} \mathrm{~F}_{1}$ cultures. The segregation of avirulent and virulent cultures in the $\mathrm{BC}_{4} \mathrm{~F}_{1}$ generation fitted a $1: 1$ ratio, and was again perfectly concordant with the segregation of colony color (Table 1).

Identification of a hidden resistance gene. To examine whether the white cultures had lost virulence on all tested wheat lines, 31 hexaploid and 32 tetraploid accessions were inoculated with a white $\mathrm{BC}_{4} \mathrm{~F}_{1}$ culture (h31-2-7). The hexaploid lines tested were all resistant to h31-2-7 (data not shown). On the other hand, the tetraploids contained four susceptible lines. T. paleocolchicum Tat14 is shown in Figure 2 and Table 1 as an example of these susceptible accessions. Tat14 was susceptible not only to all black cultures from the parents $\left(\mathrm{Br} 58\right.$ and $\mathrm{Br} 48$ ) through the $\mathrm{BC}_{4} \mathrm{~F}_{1}$ generation but also to all white cultures in the $\mathrm{BC}_{3} \mathrm{~F}_{1}$ and $\mathrm{BC}_{4} \mathrm{~F}_{1}$ generations.

These exceptional lines made it possible to identify a resistance gene in tetraploid wheat. Against white culture h22-4-7, Tat4 was resistant (3B) whereas Tat14 was susceptible (5G) (Table 1). When $F_{2}$ seedlings derived from Tat $4 \times$ Tat 14 were inoculated with h22-4-7, resistant and susceptible seedlings segregated in a 3:1 ratio (Table 2). To confirm the single-gene control, a white culture (A1-3) was chosen from the $\mathrm{BC}_{4} \mathrm{~F}_{1}$ cultures and employed for further segregation analysis. Against A1-3, Tat4 was resistant (2B) whereas Tat14 was susceptible (5G). When inoculated with A1-3, the $\mathrm{F}_{2}$ population from Tat $4 \times$ Tat14 showed a clear 3:1 segregation of resistant and susceptible seedlings (Table 2). In $\mathrm{F}_{3}$ lines derived from Tat $4 \times$ Tat 14 , homozygous resistant, segregating, and homozygous susceptible lines segregated in 20:42:24, fitting a $1: 2: 1$ ratio $\left(\chi^{2}=0.42, P_{2 \mathrm{df}}>0.05\right)$. Molecular mapping with these $\mathrm{F}_{3}$ lines revealed that this gene was located on chromosome 7B (Supplemental Figure 2). On the other hand, this gene was not detected with Br58, 73Q2 $\left(\mathrm{F}_{1}\right)$, Yt3N1 $\left(\mathrm{BC}_{1} \mathrm{~F}_{1}\right)$, or h12-1-6 $\left(\mathrm{BC}_{2} \mathrm{~F}_{1}\right)$; Tat4 and all $\mathrm{F}_{2}$ seedlings from Tat $4 \times$ Tat 14 were susceptible to these cultures (Tables 1 and 2). These observations led us to successfully detect a hidden resistance gene in wheat which was tentatively designated as $\operatorname{Rmg} T d(t)$.

This gene is not Rwt3 corresponding to PWT3, because Tat 4 is susceptible to $\mathrm{Br} 58$, 73Q2 $\left(\mathrm{F}_{1}\right)$, Yt3N1 $\left(\mathrm{BC}_{1} \mathrm{~F}_{1}\right)$, and h12-1-6 $\left(\mathrm{BC}_{2} \mathrm{~F}_{1}\right)$, which are the $P W T 3$ carriers in the pedigree. Moreover, h22-4-7 $\left(\mathrm{BC}_{3} \mathrm{~F}_{1}\right)$ and h31-2-7 $\left(\mathrm{BC}_{4} \mathrm{~F}_{1}\right)$ carried $\mathrm{Br} 48$ alleles at both of the MGM130 and MGM134 loci (Fig. 3B) which flanked $P W T 3$ on chromosome 6 (Fig. 3A). If h22-4-7 carried PWT3 (the Br58 allele) at the Pwt3 locus, crossing-over must have occurred in both flanking regions (i.e., between MGM130 and PWT3 and between PWT3 and MGM134), which is highly unlikely.

Cytological response associated with $\operatorname{Rmg} \boldsymbol{T d}(\boldsymbol{t})$. To obtain a clue to the nature of this resistance gene, cytological analysis was performed. Tat 4 and Tat 14 were fixed $60 \mathrm{~h}$ after inoculation with Br58, h22-4-7, and Br48 and examined cytologically. On both accessions, appressorial penetration by both parental isolates ( $\mathrm{Br} 48$ and $\mathrm{Br} 58)$ was blocked at the papilla stage with frequency of 1 to $5 \%$ (Table 3 ). Most of the germlings that overcame the papilla stage produced infection hyphae and effectively colonized the epidermal cells, leading to susceptible reactions.
The white culture, h22-4-7, colonized the susceptible accession Tat14 in a similar way. The most prominent cellular response in Tat4 leaves inoculated with h22-4-7 was a hypersensitive reaction of mesophyll cells (Table 3). Those mesophyll cells were accompanied by yellow fluorescence and stained with trypan blue (Fig. 4). This incompatible reaction resulted in failure to cause disease.

\section{A}

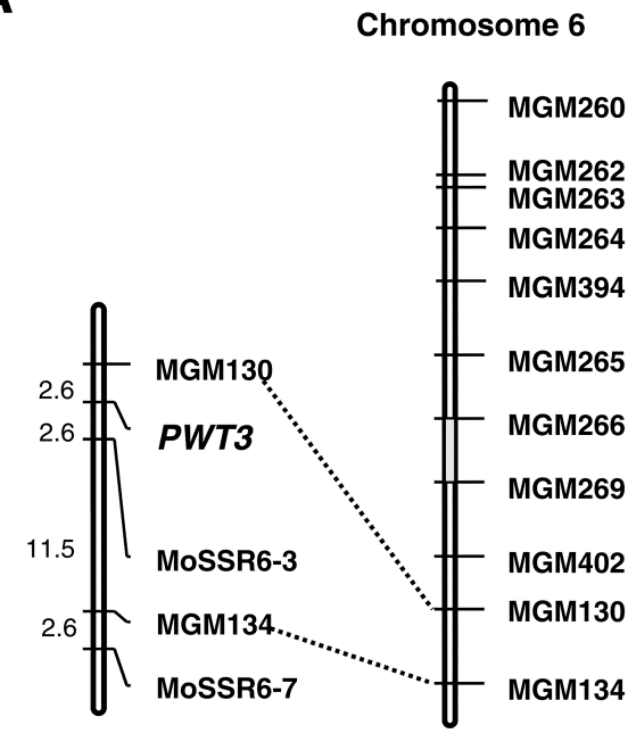

Zheng et al. (2008)

B

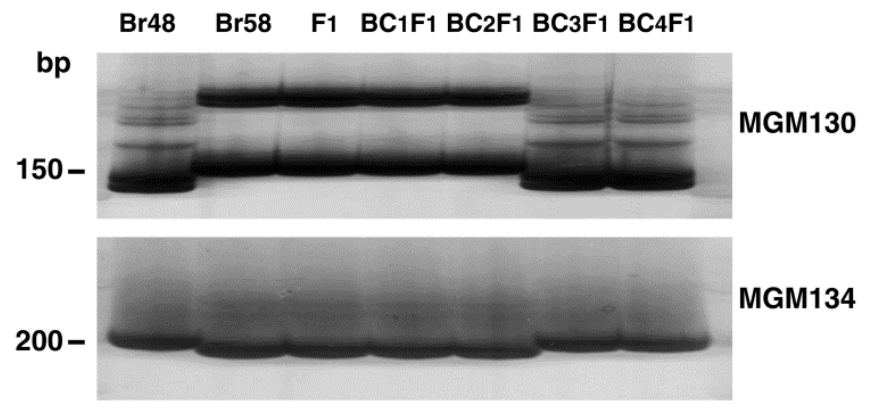

Fig. 3. Analysis of backcross progenies with molecular markers. A, Genetic map of the $P W T 3$ region constructed using a $\mathrm{BC}_{1} \mathrm{~F}_{1}$ population derived from 73Q2 $\times$ Br48. Markers prefixed with MGM are from Zheng et al. (29). Others were designed using the database of the Magnaporthe oryzae 70-15 genomic sequence. B, Polyacrylamide gel electrophoresis analysis of backcross progenies. Two PWT3-flanking simple-sequence repeat loci (MGM130 and MGM134) were amplified from genomic DNA of Br48 (Triticum isolate), $\mathrm{Br} 58$ (Avena isolate), 73Q2 $\left(\mathrm{F}_{1}\right)$, Yt3N1 $\left(\mathrm{BC}_{1} \mathrm{~F}_{1}\right), \mathrm{h} 12-1-6\left(\mathrm{BC}_{2} \mathrm{~F}_{1}\right), \mathrm{h} 22-4-7$ $\left(\mathrm{BC}_{3} \mathrm{~F}_{1}\right)$, and $\mathrm{h} 31-2-7\left(\mathrm{BC}_{4} \mathrm{~F}_{1}\right)$, and run on a $6 \%$ polyacrylamide gel.

TABLE 2. Frequency distribution of infection types with Avena isolate Br58 and its backcross progenies in $\mathrm{F}_{2}$ seedlings derived from a cross between tetraploid wheat accessions Triticum dicoccoides accession KU109 (Tat4) and T. paleocolchicum accession KU156 (Tat14)

\begin{tabular}{|c|c|c|c|c|c|c|c|c|c|c|c|c|}
\hline \multirow[b]{2}{*}{ Culture } & \multicolumn{10}{|c|}{ Number of $F_{2}$ seedlings from Tat $4 \times$ Tat $14^{a}$} & \multirow[b]{2}{*}{$\chi^{2}$ for $3: 1$} & \multirow[b]{2}{*}{$P$} \\
\hline & $0 / 1 \mathrm{~B}$ & $2 B / 2 B G$ & $3 \mathrm{~B}$ & 3BG & $3 G$ & $4 \mathrm{G}$ & $5 \mathrm{G}$ & Total & Res & Sus & & \\
\hline Br58 & 0 & 0 & 0 & 0 & 0 & 3 & 37 & 40 & 0 & 40 & $\ldots$ & $\ldots$ \\
\hline 73Q2 $\left(\mathrm{F}_{1}\right)$ & 0 & 0 & 0 & 0 & 3 & 2 & 33 & 38 & 0 & 38 & $\ldots$ & $\ldots$ \\
\hline h12-1-6 $\left(\mathrm{BC}_{2} \mathrm{~F}_{1}\right)$ & 0 & 0 & 0 & 0 & 0 & 5 & 32 & 37 & 0 & 37 & $\ldots$ & $\ldots$ \\
\hline h22-4-7 $\left(\mathrm{BC}_{3} \mathrm{~F}_{1}\right)$ & 19 & 5 & 2 & 0 & 3 & 2 & 3 & 34 & 26 & 8 & 0.04 & 0.84 \\
\hline A1-3 $\left(\mathrm{BC}_{4} \mathrm{~F}_{1}\right)$ & 39 & 33 & 9 & 0 & 5 & 2 & 15 & 103 & 81 & 22 & 0.73 & 0.39 \\
\hline
\end{tabular}

${ }^{a}$ Infection type at 5 days after inoculation: 0 to $3 \mathrm{BG}=$ resistant (Res) and $3 \mathrm{G}$ to $5 \mathrm{G}=$ susceptible (Sus). 


\section{DISCUSSION}

In the process of producing PWT3-segregating populations, we found color mutants with white mycelia. The white mutants lacked virulence on all hexaploid and most tetraploid wheat lines. The avirulent white and virulent black progeny in the $\mathrm{BC}_{4} \mathrm{~F}_{1}$ population segregated in a 1:1 ratio, suggesting single-gene control. Color mutations accompanied by pathogenicity defects have been frequently observed in the blast fungus. Chumley and Valent (2) described three classes of pigment mutants (albino, rosy, and buff) that appeared spontaneously or were recovered following mutagenesis. These mutants infected plants that had been wounded by abrading the leaf epidermis but failed to infect intact host plants (2) due to defects in melanin biosynthesis in the appressoria (8). Our mutants (white cultures) are apparently different from the pigment mutants that completely lost the basic

TABLE 3. Cytological responses of wheat accessions against Avena isolate Br58, Triticum isolate $\mathrm{Br}_{4}$, and $\mathrm{BC}_{3} \mathrm{~F}_{1}$ culture h22-4-7 derived from their crosses ${ }^{\mathrm{a}}$

\begin{tabular}{|c|c|c|c|c|c|c|c|}
\hline \multirow[b]{2}{*}{ Culture } & \multirow[b]{2}{*}{ Accession $^{b}$} & \multirow[b]{2}{*}{$\begin{array}{l}\text { Infection } \\
\text { type }\end{array}$} & \multicolumn{5}{|c|}{ Appressoria (\%) accompanied by } \\
\hline & & & $\begin{array}{l}\text { No } \\
\text { reaction }\end{array}$ & $\begin{array}{l}\text { Cell wall } \\
\text { defense }^{c}\end{array}$ & $\begin{array}{c}\text { HR of } \\
\text { epidermal cell }\end{array}$ & $\begin{array}{l}\text { Hyphal growth with HR of } \\
\text { mesophyll cells }\end{array}$ & $\begin{array}{l}\text { Hyphal growth } \\
\text { with no HR }\end{array}$ \\
\hline \multirow[t]{2}{*}{$\operatorname{Br} 58$} & Tat4 & $5 \mathrm{G}$ & 13.3 & 1.6 & 0.5 & 8.0 & 77.4 \\
\hline & Tat14 & $5 \mathrm{G}$ & 17.1 & 4.6 & 7.5 & 3.4 & 67.7 \\
\hline \multirow[t]{2}{*}{ h22-4-7 } & Tat4 & $3 B$ & 0.0 & 1.6 & 0.0 & 96.7 & 1.6 \\
\hline & Tat14 & $5 \mathrm{G}$ & 10.9 & 2.2 & 2.1 & 0.0 & 85.1 \\
\hline \multirow[t]{2}{*}{$\mathrm{Br} 48$} & Tat4 & $5 \mathrm{G}$ & 5.5 & 3.1 & 33.6 & 0.8 & 57.5 \\
\hline & Tat14 & $5 \mathrm{G}$ & 11.4 & 3.1 & 20.0 & 1.0 & 65.1 \\
\hline
\end{tabular}

a Average of two replications. More than 300 appressoria on three leaves were counted in each replication. HR $=$ hypersensitive reaction.

b Tat4 = Triticum dicoccoides accession KU109 and Tat14 = T. paleocolchicum accession KU156.

${ }^{c}$ Appressoria that attempted penetration but were stopped at the cell wall stage by papilla formation.

Tat4

A

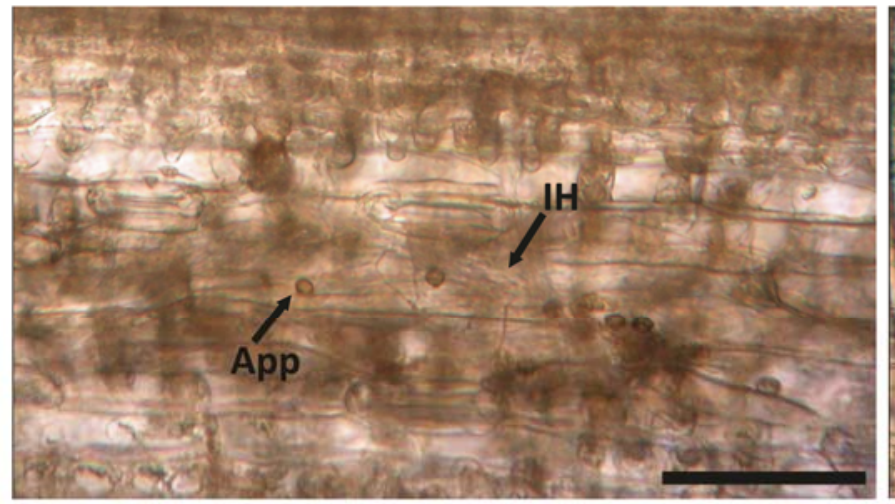

B

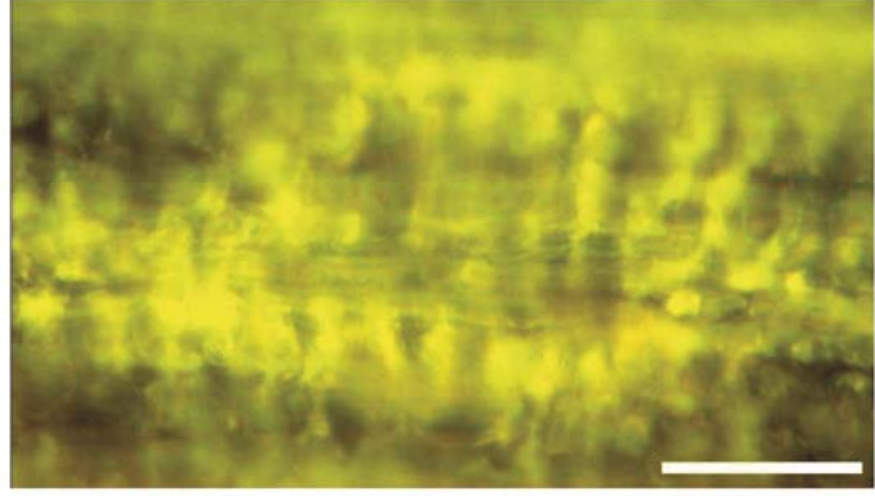

C

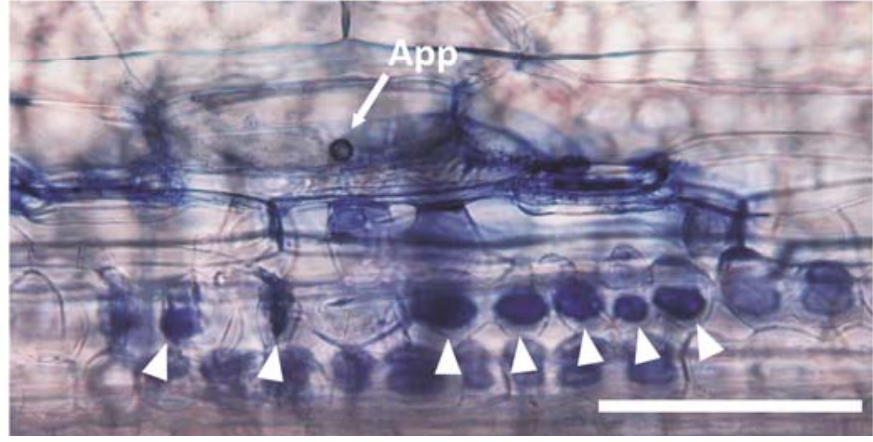

Tat14
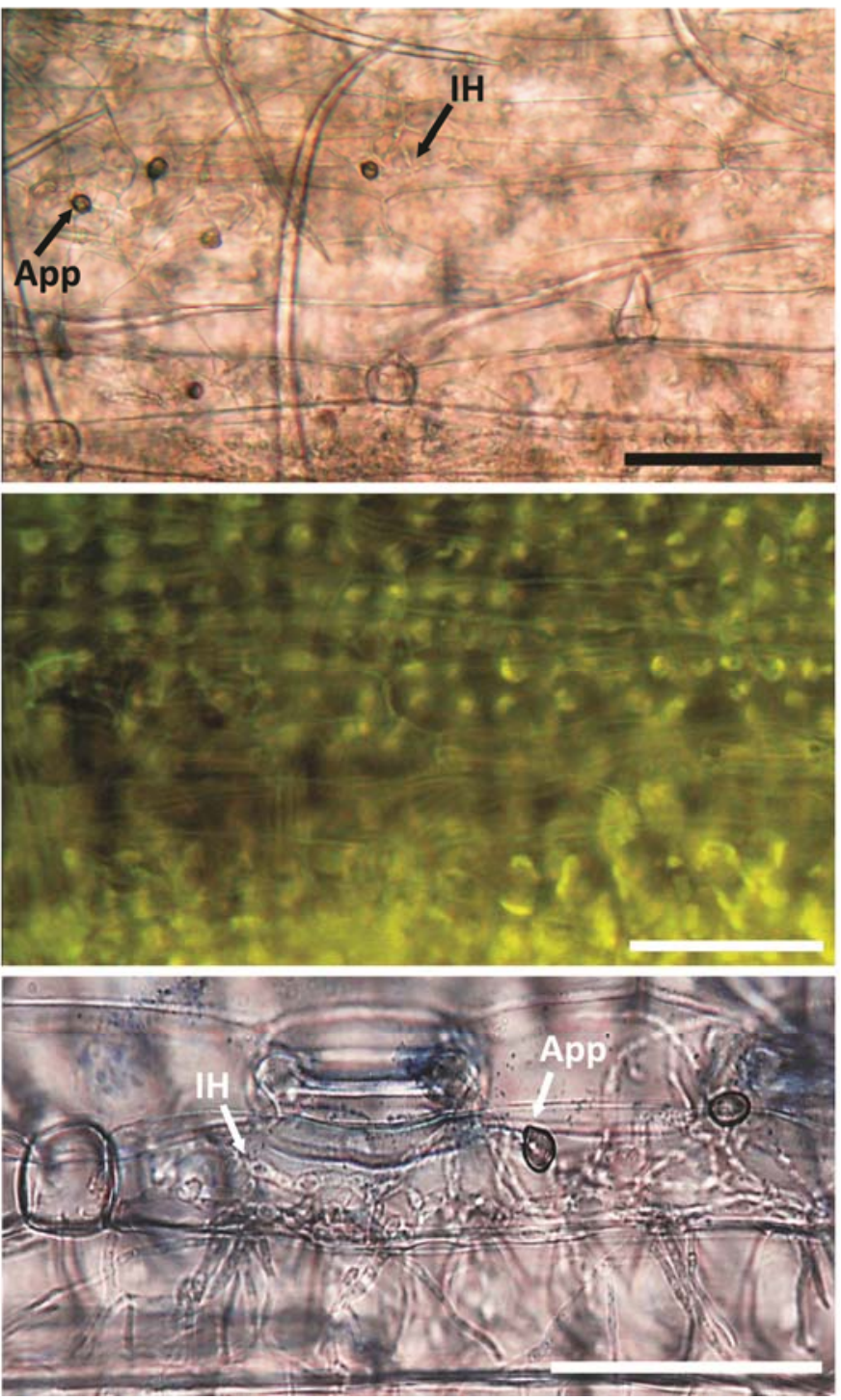

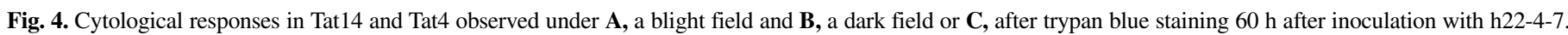

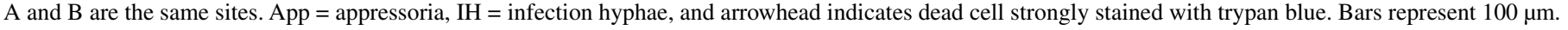


capacity of penetration. They produced dark-brown appressoria and extended infection hyphae (Fig. 4), indicating that their ability to penetrate host cell walls remains intact. In addition, they are completely virulent on some tetraploid accessions including Tat14 (Fig. 2).

The mutants we have described led us to identify a hidden resistance gene, $\operatorname{RmgTd}(t)$, located on chromosome $7 \mathrm{~B}$ in tetraploid accession Tat4. The intermediate resistance of Tat4 conditioned by $\operatorname{RgmTd}(t)$ was due to the production of infection hyphae by appressoria, which eventually induced hypersensitive responses of mesophyll cells. $\operatorname{Rmg} T d(t)$ is not $R w t 3$ corresponding to $P W T 3$ because Tat4 is susceptible to PWT3 carriers such as Br58 and the present $\mathrm{F}_{1}, \mathrm{BC}_{1} \mathrm{~F}_{1}$, and $\mathrm{BC}_{2} \mathrm{~F}_{1}$ cultures. Zhan et al. (28) found two resistance genes, Rmg2 and Rmg3, in 'Thatcher' wheat that are effective against Triticum isolates. These genes are located on chromosomes 7A and 6B, respectively. Two other wheat genes, Rmg4 and Rmg5, controlling resistance to the inappropriate species $P$. grisea (Digitaria isolates), were located on chromosomes 4A and 6D, respectively (18). Apparently, $\operatorname{RmgTd}(t)$ is different from these blast resistance genes previously identified in wheat.

The above results led us to infer the original function or targets of $\operatorname{RmgTd}(t)$. One possibility is that $\operatorname{RmgTd}(t)$ is involved in the basic machinery of disease resistance and that the four tetraploid accessions susceptible to the white mutants are defective in this gene. This seems unlikely because the four accessions are resistant to other blast isolates. For example, Tat14 is resistant to $P$. grisea Dig41 isolated from crabgrass. Another susceptible accession, T. dicoccum St16, is resistant to P. oryzae PO12-7301-2 isolated from rice (data not shown). The second possibility is that $\operatorname{RmgTd}(t)$ is a pattern recognition receptor recognizing a microbial-associated molecular pattern (MAMP) $(1,12)$. This seems also unlikely because, if this is the case, the white mutants must carry a MAMP which was absent in the wild isolates and newly produced by a mutation during the backcrossing. This idea contradicts the definition of MAMPs, which must be ubiquitous in microbes. The third possibility is that the effect of $\operatorname{RmgTd}(t)$ was not enough to arrest infection of young seedlings with aggressive wild isolates and became apparent at a later stage, with development of adult resistance, but that the pigment mutation reduced the aggressiveness of the isolates and made its effect detectable at the primary leaf stage. The fourth possibility is that $\operatorname{RmgTd}(t)$ is a potential resistance gene with no targets or a resistance gene against other microbes but happened to recognize the product of the mutated fungal gene.

It should be noted that incompatibility occurs only when $\operatorname{RmgTd}(t)$ matches the fungal gene associated with the color mutation. From a genetic viewpoint, therefore, the gene responsible for the pigment and virulence defects looks like an avirulence gene corresponding to $\operatorname{RmgTd}(t)$ involved in a gene-for-gene interaction. Further studies are needed to clone the gene responsible for the unique characteristics of the mutant.

\section{ACKNOWLEDGMENTS}

We thank S. Takumi, Kobe University, for providing primers for the SSR markers, and B. McIntosh, University of Sydney, for critical reading and editing of the manuscript. This study was supported by research grants for JSPS (Japan Society for the Promotion of Science) Postdoctoral Fellows No. 21-09107 for the first author.

\section{LITERATURE CITED}

1. Chisholm, S. T., Coaker, G., Day, B., and Staskawicz, B. J. 2006. Hostmicrobe interactions: shaping the evolution of the plant immune response. Cell 124:803-814.

2. Chumley, F. G., and Valent B. 1990. Genetic analysis of melanindeficient, nonpathogenic mutants of Magnaporthe grisea. Mol. PlantMicrobe Interact. 3:135-143.
3. Couch, B. C., and Kohn, L. M. 2002. A multilocus gene genealogy concordant with host preference indicates segregation of a new species, Magnaporthe oryzae, from Magnaporthe grisea. Mycologia 94:683-693

4. Eto, Y., Ikeda, K., Chuma, I., Kataoka, T., Kuroda, S., Kikuchi, N., Don, L. D., Kusaba, M., Nakayashiki, H., Tosa, Y., and Mayama, S. 2001. Comparative analyses of the distribution of various transposable elements in Pyricularia and their activity during and after the sexual cycle. Mol. Gen. Genet. 264:565-577.

5. Flor, H. H. 1956. The complementary genic systems in flax and flax rust. Adv. Genet. 8:29-54.

6. Hayashi, N., and Kato, H. 1988. Viability and aggressiveness of Pyricularia cultures preserved by silica gel-dried grain method. Proc. Kanto-Tosan Plant Prot. Soc. 35:12-13. (In Japanese)

7. Heath, M. C. 1981. A generalized concept of host-parasite specificity. Phytopathology 71:1121-1123.

8. Howard, R. J., and Valent, B. 1996. Breaking and entering: host penetration by the fungal rice blast pathogen Magnaporthe grisea. Annu. Rev. Microbiol. 50:491-512.

9. Hyon, G.-S., Nga, N. T. T., Chuma, I., Inoue, Y., Asano, H., Murata, N., Kusaba, M., and Tosa, Y. 2012. Characterization of interactions between barley and various host-specific subgroups of Magnaporthe oryzae and M. grisea. J. Gen. Plant Pathol. 78:237-246.

10. Igarashi, S. 1990. Update on wheat blast (Pyricularia oryzae) in Brazil. Pages 480-483 in: Proc. Int. Conf. Wheat Nontraditional Warm Areas. D. A. Saunders, ed. CIMMYT, Mexico D.F., Mexico.

11. Inoue, Y., Mori, R., Takahashi, Y., Kiguchi, S., Enomoto, T., Chuma, I., and Tosa, Y. 2013. Identification and molecular mapping of a wheat gene for resistance to an unadapted isolate of Colletotrichum cereale. Phytopathology 103:575-582.

12. Jones, J. D. G., and Dangl, J. L. 2006. The plant immune system. Nature 444:323-329.

13. Kachroo, P., Leong, S. A., and Chattoo, B. B. 1994. Pot2, an inverted repeat transposon from the rice blast fungus Magnaporthe grisea. Mol. Gen. Genet. 245:339-348.

14. Kato, H., Yamamoto, M., Yamaguchi-Ozaki, T., Kadouchi, H., Iwamoto, Y., Nakayashiki, H., Tosa, Y., Mayama, S., and Mori, N. 2000. Pathogenicity, mating ability and DNA restriction fragment length polymorphisms of Pyricularia populations isolated from Gramineae, Bambusideae and Zingiberaceae plants. J. Gen. Plant Pathol. 66:30-47.

15. Khush, G., and Jena, K. K. 2009. Current status and future prospects for research on blast resistance in rice (Oryza sativa L.) In: Advances in Genetics, Genomics and Control of Rice Blast Disease. G. L. Wang and B. Valent, eds. Springer Science and Business Media, New York.

16. Murakami, J., Tosa, Y., Kataoka, T., Tomita, R., Kawasaki, J., Chuma, I., Sesumi, Y., Kusaba, M., Nakayashiki, H., and Mayama, S. 2000. Analysis of host species specificity of Magnaporthe grisea toward wheat using a genetic cross between isolates from wheat and foxtail millet. Phytopathology 90:1060-1067.

17. Nakayashiki, H., Kiyotomi, K., Tosa, Y., and Mayama, S. 1999. Transposition of the retrotransposon MAGGY in heterologous species of filamentous fungi. Genetics 153: 693-703.

18. Nga, T. T., Hau, V. T. B., and Tosa, Y. 2009. Identification of genes for resistance to a Digitaria isolate of Magnaporthe grisea in common wheat. Genome 52:801-809.

19. Oh, H. S., Tosa, Y., Takabasyashi, N., Nakagawa, S., Tomita, R., Don, L. D., Kusaba, M., Nakayashiki, H., and Mayama, S. 2002. Characterization of an Avena isolate of Magnaporthe grisea and identification of a locus conditioning its specificity on oat. Can. J. Bot. 80:1088-1095.

20. Ou, S. H. 1985. Pages 109-201 in: Rice Diseases. Commonwealth Agricultural Bureaux, Slough, UK.

21. Silue, D., Notteghem, J. L., and Tharreau, D. 1992. Evidence for a genefor-gene relationship in the Oryza sativa-Magnaporthe grisea pathosystem. Phytopathology 82:577-582.

22. Somers D. J., Isaac, P., and Edwards, K. 2004. A high density microsatellite consensus map for bread wheat (Triticum aestivum L.). Theor. Appl. Genet. 109:1105-1114.

23. Takabayashi, N., Tosa, Y., Oh, H. S., and Mayama, S. 2002. A gene-forgene relationship underlying the species-specific parasitism of Avena/Triticum isolates of Magnaporthe grisea on wheat cultivars. Phytopathology 92:1182-1188.

24. Torada, A., Koike, M., Mochida, K., and Ogihara, Y. 2006. SSR-based linkage map with new markers using an intraspecific population of common wheat. Theor. Appl. Genet. 112:1042-1051.

25. Tosa, Y., Hirata, K., Tamba, H., Nakagawa, S., Chuma, I., Isobe, C., Osue, J., Urashima, A. S., Don, L. D., Kusaba, M., Nakayashiki, H., Tanaka, A., Tani, T., Mori, N., and Mayama, S. 2004. Genetic constitution and pathogenicity of Lolium isolates of Magnaporthe oryzae in comparison with host species-specific pathotypes of the blast fungus. Phytopathology 
94:454-462.

26. Urashima, A. S., Igarashi, S., and Kato, H. 1993. Host range, mating type and fertility of Pyricularia grisea from wheat in Brazil. Plant Dis. 77:1211-1216.

27. Urashima, A. S., and Kato, H. 1994. Varietal resistance and chemical control of wheat blast fungus. Summa Phytopathol. 20:107-112.

28. Zhan, S. W., Mayama, S., and Tosa, Y. 2008. Identification of two genes for resistance to Triticum isolates of Magnaporthe oryzae in wheat. Genome 51:216-221.

29. Zheng, Y., Zhang, G., Lin F., Wang, Z., Jin, G., Yang, L., Wang, Y., Chen, X., Xu, Z., Zhao, X., Wang, H., Lu, J., Lu, G., and Wu, W. 2008. Development of microsatellite markers and construction of genetic map in rice blast pathogen Magnaporthe grisea. Fungal Genet. Biol. 45:13401347. 